\title{
DESCRIPTION OF A NEW TRIBE CABRALCANDONINI (CANDONIDAE, OSTRACODA) FROM KARST AQUIFERS IN CENTRAL TEXAS, U.S.A.
}

\author{
Okan Külköylüoğlu1, c, Mehmet Yavuzatmaca1, Derya Akdemir², Benjamin F. Schwartz ${ }^{3,4}$, Benjamin \\ T. Hutchins ${ }^{4,5}$
}

\begin{abstract}
Cabralcandonini tribe n., with the type genus Cabralcandona gen. n. from an artesian well in the San Marcos, Texas (U.S.A.) and six other genera from karst aquifers in Texas, is proposed as a new tribe of the subfamily Candoninae (Candonidae) (Crustacea, Ostracoda). The new tribe and genus have morphological features that distinguish them from other members of the subfamily. The most diagnostic characteristics of the type genus are (1) two horn-like structures developed on the antero- and postero-dorsal margins of the left valve, (2) numbers of central muscle scars, (3) hexagonal or pentagonal (honeycomb-like) ornamentation on the subrectangular shaped carapace, (4) four segmented second antenna in both sexes, (5) absence of an exopod on A2, (6) shape and size of $Y$ aesthetasc, (7) absence of e, $f$ and $g$ setae on cleaning leg, (8) flagellum (whip-like) uropod morphology, (9) shape of hemipenis, and (10) reduction in number of segments and setae on other limbs. Taxonomic keys for the tribes of the subfamily Candoninae including Cabralcandonini tribe $\mathrm{n}$. are presented.
\end{abstract}

\section{Introduction}

Artesian wells are windows into otherwise inaccessible deep aquifer systems, and flowing artesian wells bring groundwater directly from the aquifer to the land surface. The name "artesian" traces its origins to the Province of Artois, France (Carpenter, 1891), where artesian groundwaters have been tapped for centuries. Natural and man-made artesian systems can support human usage, hypogean organisms, and many ecosystems including lentic and lotic aquatic habitats (Danielopol, 1978; Holsinger and Longley, 1980; Ponder, 2004; Külköylüoğlu, 2009; Culver and Pipan, 2009; Garza et al., 2015).

Artesian wells often discharge hypogean organisms, and some wells have a long history of intensive biological monitoring and sampling. Because of these efforts, and the fact that they allow access into an otherwise-inaccessible ecosystem, some artesian wells are associated with unique and high species diversity. Increasing our knowledge of groundwater species abundance and diversity, along with the biogeographic and ecologic processes that have contributed to observed diversity patterns, can support sound conservation activities and policies (Lopez et al., 2017).

Ostracods are small (adult freshwater forms range from 0.3 to $5.4 \mathrm{~mm}$ in length) aquatic invertebrates and are one of the most abundant and diverse groups of Crustacea. They can be found in almost all marine to freshwater habitats in natural (springs, creeks, rivers, pools, lakes, ditches etc.) and artificial settings (e.g., troughs, wells, canals, dams, ponds, etc.). Ostracods have a pair of valves (a carapace) composed of low magnesium / calcium ratio calcite (Chivas et al., 1986). Because of this calcified carapace, ostracods can be fossilized in sediments and are known from at least the Silurian period, about $425 \mathrm{Ma}$ (Siveter, 2008; Williams et al., 2008). Individual species prefer certain environmental conditions (Külköylüoğlu, 1998), therefore, ostracods are excellent model organisms for evolutionary (Cohen and Johnston, 1987; Chaplin and Ayre, 1997), ecological (De Deckker, 1981; Külköylüoğlu, 2009), biological (Kesling and Crafts, 1962; Lopez et al., 2002) and paleontological studies (Tunoğlu, 2002; Tuncer and Tunoğlu, 2015). In addition, they are useful as indicators of water quality (Hoff, 1942; Wise, 1961; Bromley and Por, 1975; Benson, 1990; Mezquita et al., 1999; Külköylüoğlu and Vinyard, 2000).

The family, Candonidae, known for its worldwide distribution (Danielopol, 1978; Danielopol et al., 2011; Smith, 2011), contains at least 515 species (Martens and Savatenalinton, 2011; Külköylüoğlu et al., 2017a-e). Karanovic (2018) stated that no species of Candonopsini have ever been recorded from North America due to a lack of freshwater ostracod studies on the continent, failing to recognize the several genera and species (e.g., Comalcandona, Lacrimacandona, Ufocandona, Rugosuscandona) reported from Texas groundwaters (Külköylüoğlu et al., 2011; 2017a-d; 2018). Although there is debate about the taxonomic position of some species (see. e.g., Higuti and Martens, 2012; 2014), there are more than 46 genera described in the subfamily Candoninae (Karanovic, 2001; Külköylüoğlu et al.,_2011; Külköylüoğlu et al., 2017a-e; Külköylüoğlu and Gibson, 2018). Most recently, descriptions of 5 new species from Texas (Külköylüoğlu

${ }^{1}$ Department of Biology, Faculty of Arts and Science, Bolu Abant Izzet Baysal University, 14280, Bolu, Turkey.

${ }^{2}$ Institute of Geology and Mineralogy, University of Cologne, Zülpicher Straße 49A, 50674 Cologne, Germany.

${ }^{3}$ Edwards Aquifer Research and Data Center, Texas State University, San Marcos, TX 78666, USA

${ }^{4}$ Department of Biology, Texas State University, San Marcos, TX 78666, USA

${ }^{5}$ Texas Parks and Wildlife Department, 4200 Smith School Road, Austin TX 78744, USA

'Corresponding Author: kulkoyluoglu o@ibu.edu.tr 
et al., 2017a-e) increased the number of known species in the subfamily to 47 with 10 genera in North America. Of these, there are now more than 33 species endemic to North America (Karanovic, 2006; Külköylüoğlu et al., 2017a-e). Because of known undescribed taxa and a lack of studies in the area, these numbers are believed to be underestimated for the subfamily.

Here, we propose Cabralcandonini tribe $\mathrm{n}$. and Cabralcandona gen. $\mathrm{n}$. with the type species (Cabralcandona mixoni sp. n.) from the San Marcos Artesian Well, San Marcos, Texas, U.S.A.: the sixth genus found and described from this well. Six genera (Ufocandona, Rugosuscandona, Lacrimacandona, Schornikovdona, Comalcandona, Bicornucandona) previously included in other tribes are also transferred into the new tribe due to shared characteristics in carapace and soft body parts (see Külköylüoğlu et al., 2017a,b).

\section{Methods}

\section{Site Description}

The San Marcos Artesian Well (SMAW) (Fig. 1) is known for its exceptional biodiversity (Longley, 1981; Culver and Sket, 2000; Hutchins et al., 2014, 2016; Külköylüoğlu et al., 2017a-e; Külköylüoğlu and Gibson, 2018). It was completed in a relatively shallow portion of the confined zone of the San Antonio Pool in the Edwards Aquifer of Texas in 1895 (Stejneger, 1896). At $59.5 \mathrm{~m}$ deep, the well intersects a $1.5 \mathrm{~m}$ tall conduit (Holsinger and Longley, 1980) from which the water and biological materials are presumed to discharge. Excluding the new species proposed herein, 36 stygobiont species are known from the well (Hutchins 2018), and the number is rapidly increasing as renewed efforts describe undocumented diversity. Ten of these species (an undescribed erpobdellid leech, the cyclopoid copepod Cyclops cavernarum Ulrich, 1902, the asellid isopod Lirceolus smithii (Ulrich 1902), the helminth parasites Amphibiocapillaria texensis Moravec \& Huffman 2000 and Dendronucleata americana Moravec \& Huffman 2000, and five ostracods (Külköylüoğlu et al., 2017a-e)) are only known from the single site or the nearby San Marcos Spring (Chippindale, 2000; Hutchins et al., 2014, 2016; Külköylüoğlu et al., 2017a-e). More than 50 \% of the 51 described stygobiont species known from this central Texas region are endemic to the Edwards Aquifer (Hutchins, 2018). However, considering the number of documented undescribed taxa and lack of in-depth studies in the region, the actual diversity of the well and aquifers are unknown, and higher species richness certainly exists (Schwartz et al., 2018).

Water quality is generally high at the site, which has been dye traced to San Marcos Springs, less than $1 \mathrm{~km}$ to the northeast (see details in Ogden et al., 1986). In November 2013, water temperature at the well averaged $22.3^{\circ} \mathrm{C}$ (SD \pm 0.01 ), dissolved oxygen averaged $5.3 \mathrm{mg} / \mathrm{l}(\mathrm{SD} \pm 0.01)$ and electrical conductivity averaged $608 \mu \mathrm{S} / \mathrm{cm}(\mathrm{SD} \pm 0.50)$.

\section{Sample Collection and Description}

All materials were collected from the type locality (Fig. 1) with a drift-net (100 $\mu \mathrm{m}$ mesh size) placed on the outflow pipe. Sample collection intervals ranged from 24 to 72 hours, and each sample was sorted under a dissecting microscope to count and identify all invertebrates to lowest taxonomic level (species, for most organisms). All organisms were stored in $95 \%$ ethanol in glass vials with poly-seal caps.

Ostracods were dissected in lactophenol solution using fine needles under a stereomicroscope, and soft body parts were mounted on glass slides, covered with coverslips, and sealed with clear fingernail polish. Each slide was labeled with a unique catalog number. Valves were kept in micropaleontological slides whenever possible. External views of carapace and valves were acquired by Scanning Electron Microscope (JEOL 6335 F SEM) after ostracods were prepared with hexamethyldisilazane (HMDS) as a drying agent at the TÜBITAK-MAM Institute (Gebze, Turkey). SEM images of the internal views of the valves were also taken with Scanning Electron Microscope at the Research Service Center, Texas State University (U.S.A.). Line drawings of the soft body parts of holotype and allotype specimens were made with a camera lucida (Olympus U-DA) attached to an Olympus BX-51 microscope before the drawings were digitized in Adobe lllustrator CS5 (ADOBE). The following literature was used during species description: Broodbakker and Danielopol, 1982; Martens, 1987; Meisch, 2000, and Karanovic, 2004, 2005a-c, 2006, 2007, 2011, 2012, $2013,2018$. Methodological details can be found in Külköylüoğlu et al. (2017a-e). Materials and slides prepared for identification (catalog numbers OK-TX-AW036-055: 07-12) are stored at the Limnology Laboratory of the Biology Department, Abant İzet Baysal University (Bolu, Turkey), and are available upon request.

\section{Clustering Analyses}

WinClada, version 1.00 .08 (Nixon, 2002) along with the NONA program was used to elucidate best clustering relationships among 49 genera of the subfamily Candoninae. Two outgroup genera, Cypria and Cyclocypris, were chosen due to their distinct morphological characteristics compared to genera of the subfamily (for details see Karanovic, 2007). All of the 31 morphological characters (Table 1) and taxa used in the reduced model of Karanovic (2007) were included. We added 5 more characters and 10 genera published since 2007 to this data matrix (Table 1). Additional characters were chosen based on their importance for identification and prevalence in current taxonomic keys (e.g., see Meisch, 2000; Karanovic, 2007, 2012; Higuti and Martens, 2012, 2014). For example, there were no character states of Mxl in the origi- 


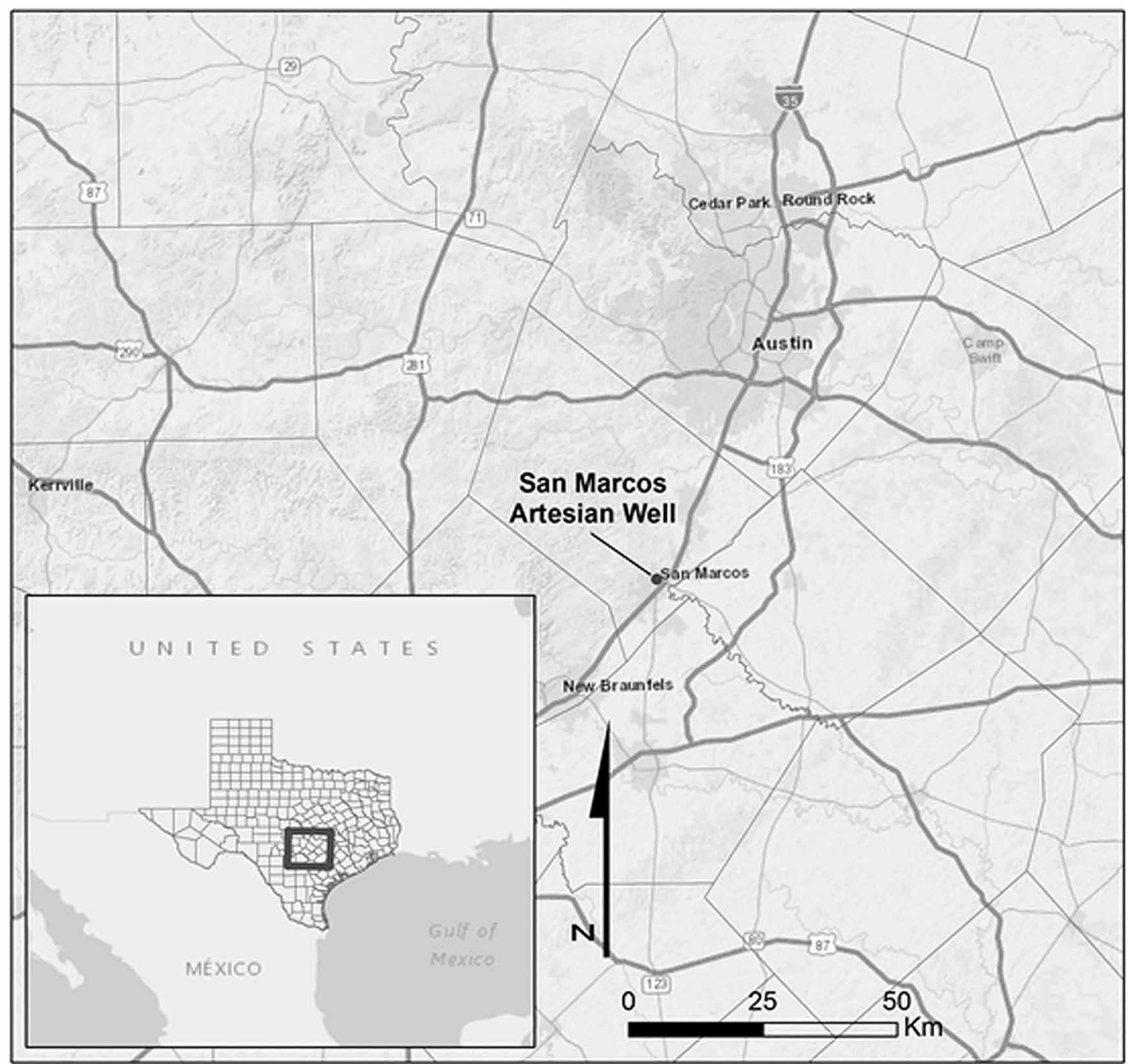

Figure 1. Type locality of Cabralcandona mixoni gen. et sp. nov. from Texas, U.S.A. nal data matrix of Karanovic (2007). However, Mxl appears around the 7th larval (A7) stage (Meisch, 2000; Smith and Martens, 2000; Díaz and Lopretto, 2017) and is therefore an important character used in taxonomic keys. All characters in the data matrix were coded and weighted during computation of consistency (Ci) and retention (Ri) indices. As described in Karanovic (2007), except for the characters $23-30$ and 33 , which were weighted by 2 , all characters were weighted by 1 . Phylogenetic analysis was conducted via a heuristic search in WinClada-Nona along with the following default parameters of the Rachet Island Hopper application whenever possible: 200 replications; 1 tree to hold/

iteration; 3 characters to sample; 10 random constraint levels and amb-poly= (amb: collapsing a branch if the ancestor and descendant have different states under the same resolutions of multi state characters or character states are unknown; poly: treating trees as collapsed). During which, tree bisection and reconnection (TBR+TBR) method of branch-swapping was repeated to search for the trees where the tree is cut about half and reconnected the remaining branches.

\section{Abbreviations}

A1, first antenna; A2, second antenna; G1-G3 and GM, Gm, claws on A2; H, height; L, length; LV, left valve; Md, mandibula; Mxl, maxillula; RV, right valve; T1, first thoracopod; T2, second thoracopod; T3, third thoracopod; UR, uropod; W, width.

\section{Results}

\section{Systematic Description}

Class: Ostracoda Latreille, 1802

Subclass: Podocopa Sars 1866

Order: Podocopida Sars, 1866

Suborder: Cypridocopina Baird, 1845

Superfamily: Cypridoidea Baird, 1845

Family: Candonidae Kaufmann, 1900

Subfamily: Candoninae Kaufmann, 1900

Tribe: Cabralcandonini tribe $\mathrm{n}$. 


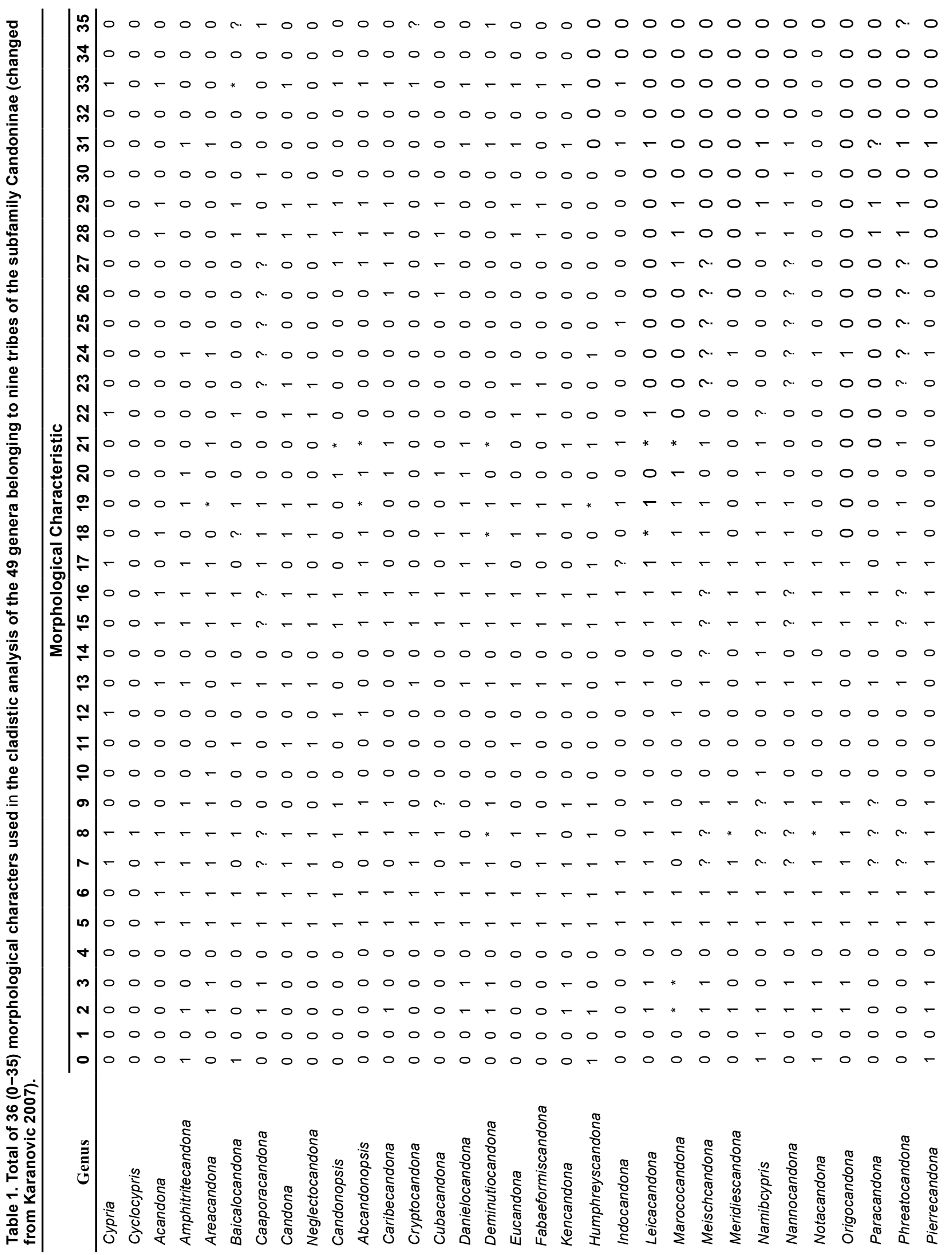




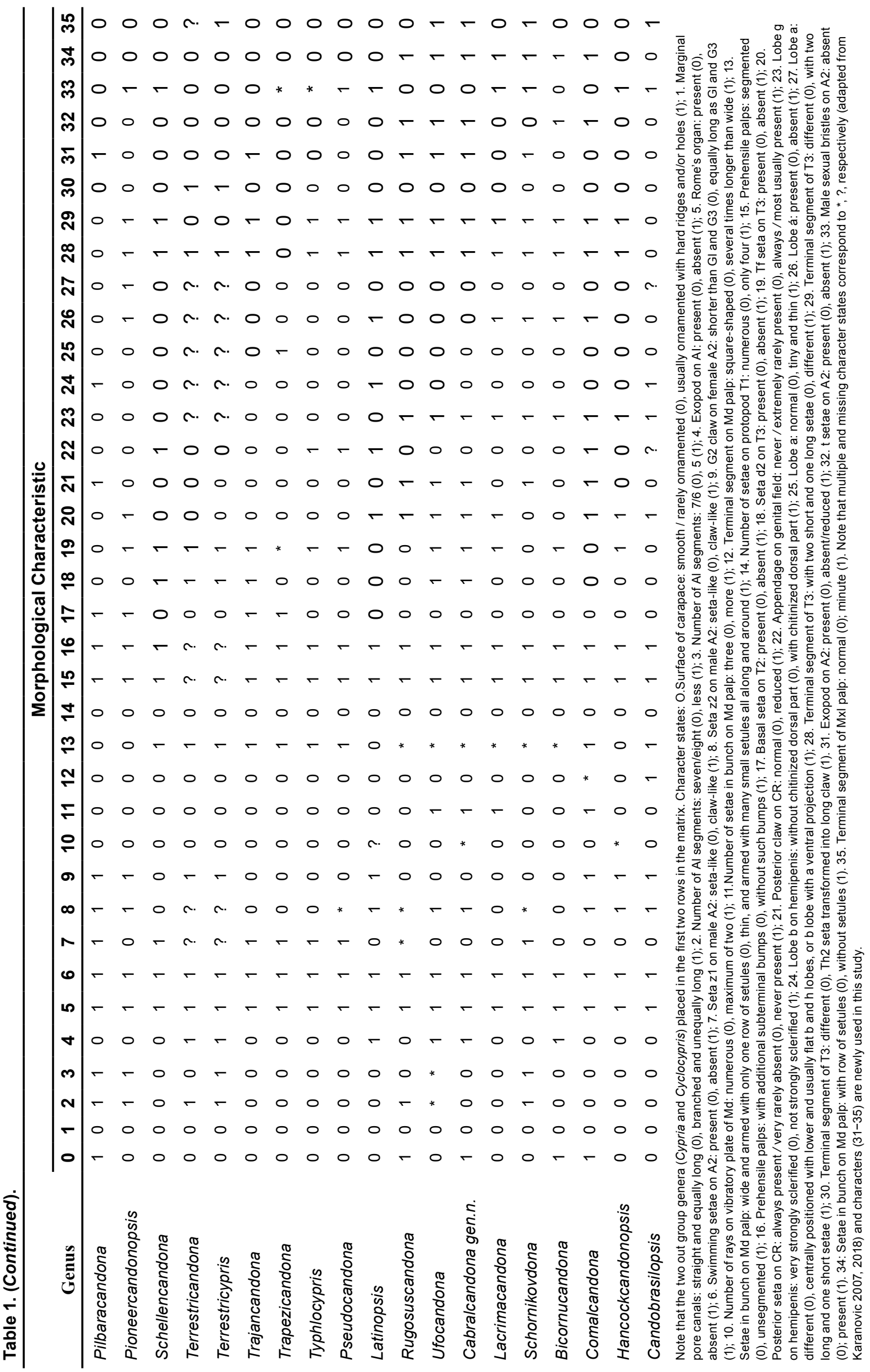


Type genus: Cabralcandona gen. $\mathrm{n}$.

Other genera: Bicornucandona Külköylüoğlu et al., 2011, Rugosuscandona Külköylüoğlu et al., 2017, Ufocandona Külköylüoğlu et al., 2017, Lacrimacandona Külköylüoğlu et al., 2017, Schornikovdona Külköylüoğlu et al., 2017, Comalcandona Külköylüoğlu and Gibson 2017.

Etymology. The name is a combination of the last name of Dr. Maria Cristina Cabral with the genus Candona of the subfamily Candoninae. Gender feminine.

Diagnosis: A small candonine ( $<0.5 \mathrm{~mm}$ in average). Carapace subrectangular (or at most one valve oval). Carapace partially or fully ornamented with hexagonal and/or pentagonal cells. Pore canals short to long with sensory setae. Four to five central muscle scars (also see discussion). Dorsally, carapace wide or narrow. Inner lamella broader on at least one marginal side than the other. Inner lamella with or without node-like structure (tubercules). A1 six- to eight-segmented. A2 four-segmented without exopod. 11-4-setae absent or not transformed to bristles in male. Aesthetasc $Y$ very long with at least two segments. Md palp with a squarish terminal segment fused with medial claw. Third endite of MxI with one or two smooth bristles. Prehensile palps of T1 not segmented and symmetric to slightly asymmetric. T2 five-segmented with one basal (d1) seta. T3 four segmented without dp seta and e seta. Terminal segment of T3 with two long and one short setae. UR with one anterior claw and rami or flagellum (whip) type (cf. Cypridopsinae type), without setae. Hemipenis moderate in size and with rounded $h$ lobe. Zenker's Organ small, with six or seven whorls of spines. Female genital field without processes.

Genus Cabralcandona gen. $\mathbf{n}$.

Type species: Cabralcandona mixoni sp. $\mathrm{n}$.

Other species: The genus is presently monospecific.

Etymology. The generic name is dedicated to the genus Candona after Dr. Maria Cristina Cabral for her continuous contribution to the knowledge and work on Ostracoda. Gender feminine.

\section{Diagnosis.}

In lateral view, carapace subrectangular, LV overlaps RV. LV with two horns; one dorso-anteriorly and one dorso-posteriorly. In dorsal view, carapace is very narrow with greatest width near mid-line. Hinge adont. Valve surface ornamented with hexagonal cells with normal pores bearing sensory setae. Internal view, LV with 8-10 well-developed tubercules ventrally on the posterior end. Four to five muscle scars visible in about the center of the valves. RV without such tubercules. A1 seven-segmented. A2 four-segmented with a well-developed claw-like seta on protopodite in both sexes. Exopodial plate and setae absent. $t$ setae absent. Aesthetasc $Y$ very long. G1-3 claws dimorphic in sexes, G2 claw in females long, about the same length as all segments. Md palp with a wide terminal segment and with three claws, claw in the middle fused with terminal segment. Gamma seta absent. Mxl-palp with a very short terminal segment. Third endite with one short, smooth bristle. Prehensile palps slightly asymmetric in the males. No vibratory plate and no a seta present in T1. T2 five-segmented with one long basal seta (d1). T3 four-segmented with one basal seta (d1), "e-f-g" setae absent. Terminal segment of T3 with two long and one slightly shorter claw-like setae. UR with flagellum type (rod-like) anterior claw, without setae and posterior claw. Hemipenis with rounded $h$ lobe. Zenker's organ with seven $(5+2)$ whorls of spines. Female genital field small, without appendages.

Type species: Cabralcandona mixoni sp. n. (Figs 2-5)

Etymology. The species is named after Bill Mixon for his contributions to the Texas Speleological Survey, Texas Cave Management Association, and Association for Mexican Cave Studies.

Type locality. San Marcos Artesian Well (SMAW), Hays County, Texas, U.S.A.:

$29^{\circ} 53^{\prime} 22.5^{\prime \prime} \mathrm{N},-97^{\circ} 56^{\prime} 11.3^{\prime \prime} \mathrm{W}, \sim 177 \mathrm{~m}$ ASL.

\section{Material Examined.}

Holotype: One male dissected, with soft body parts in lactophenol solution and sealed with translucent nail polish on one slide (no: OK-TX-AW036:01). Valves kept in micropaleontological slides (no: OK-TX-AW036:02). Collected on April 15, 2013 by Benjamin F. Schwartz and Benjamin T. Hutchins from the type locality.

Allotype: One female dissected, with soft body parts in lactophenol solution and sealed with translucent nail polish on one slide (no: OK-TX-AW36:03-04). Collected on April 15, 2013 by Benjamin F. Schwartz and Benjamin T. Hutchins from the type locality.

Dissected paratypes: One male (no: OK-TX-AW052:05-06) and one female (no: OK-TX-AW052:07-08) from the type locality. Collected November 29, 2013 by Benjamin F. Schwartz and Benjamin T. Hutchins from type locality.

Non-dissected paratypes: three males and four females, and six juveniles kept in $70 \%$ ethanol. Collected on May 21, 22, and 23, 2013; November 6, 16, and 29, 2013; December 5, 9, 13, and16, 2013; June 23 and 26, 2015; July 30, 2015; December 7, 2015 and November 2, 2016 by Benjamin F. Schwartz and Benjamin T. Hutchins from the type locality. 


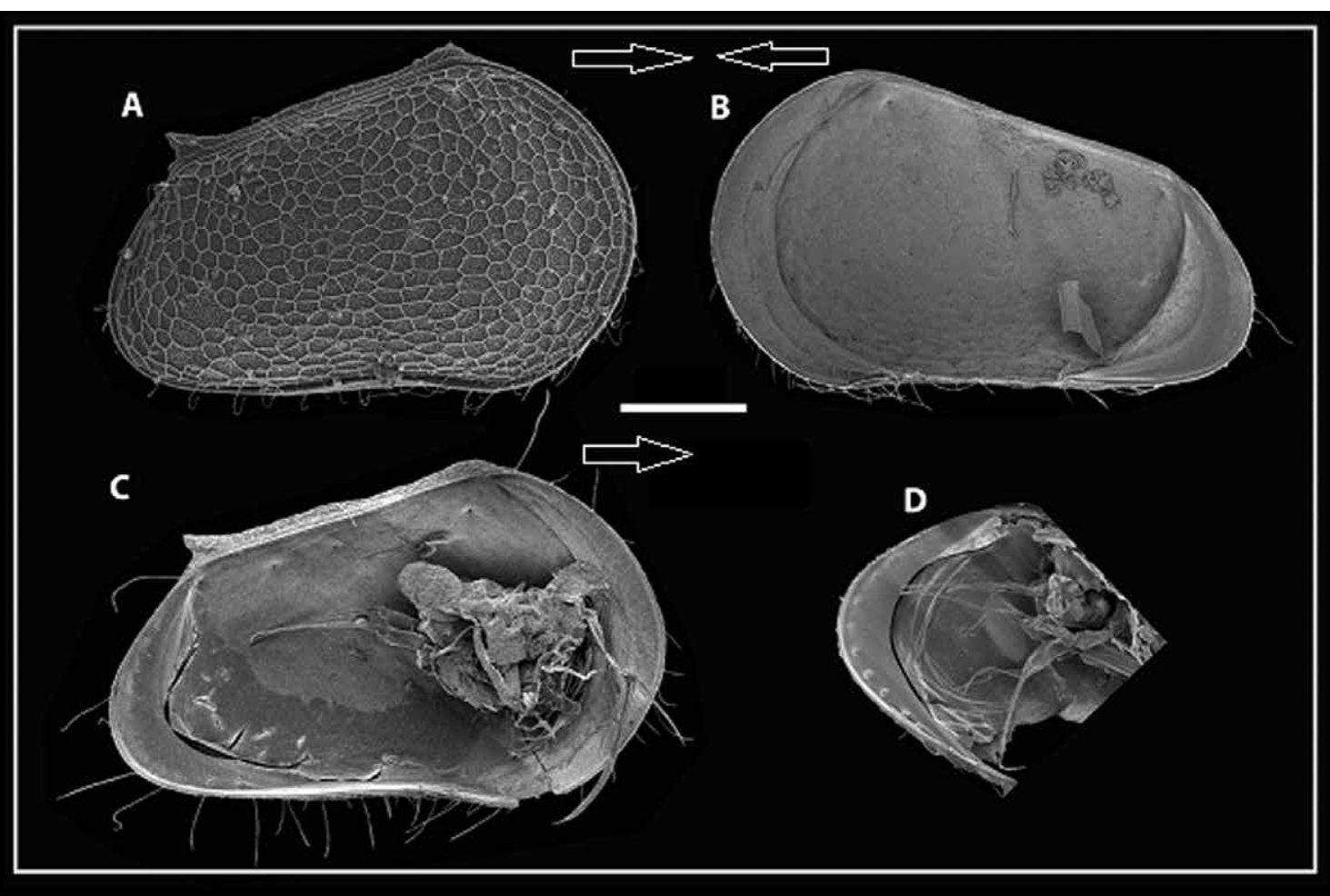

Figure 2. Cabralcandona mixoni gen. et sp. nov. male (A-C), female (D). A) Right side external view of whole carapace; B) RV internal view; C) LV internal view; D) LV internal view with node-like tubercles on posterior end. Arrows point anteriorly. Scale bar: $100 \mu \mathrm{m}$.

\section{Description}

Diagnosis: The diagnosis of the new species is similar to that of the genus.

Male: Measurements: $L=0.44$ $0.52 \mathrm{~mm}$ (average $0.48 \mathrm{~mm})(\mathrm{n}=3)$, $\mathrm{H}=0.27-0.30 \mathrm{~mm}$ (average $0.28 \mathrm{~mm}$ ) $(\mathrm{n}=3), \mathrm{W}=0.13$ $0.14 \mathrm{~mm}$ (average $0.14 \mathrm{~mm})(\mathrm{n}=2)$. LV overlapping RV from all sides (Fig. 2A). Carapace subrectangular in lateral view. Anterior margin rounded and broader than posterior margin, dorsal margin tapering posteriorly. Greatest height located in front of mid-length closer

to anterior margin (Fig. 2A-C). Carapace surface ornamented with wrinkled hexagonal cells, with small angular crenulated ridges inside these cells (Figs. 3D-F). Dorsal margin straight (not rounded). LV with two well-developed horn-like structures dorsally, anterior one slightly bent over RV (Fig. 2C). Normal pore canals with long sensory setae (Fig. 3F). Marginal pore canals reduced or short and not branched. Hinge adont. Carapace thick and opaque white in color. Four to five central muscle scars located near center (Fig. 3E. In dorsal view, carapace is fusiform-shaped, anterior margin more pointed and compressed than posterior end. Calcified inner lamella in RV smooth, slightly broader on posterior margin than on anterior margin (Fig. 2B). LV with 8-10 node-like tubercules posteriorly (Fig. 2C). Fused zone wide in both ends. Selvage thin in LV, not seen in RV.

A1 (Fig. 4A): seven-segmented. First segment articulated, with two anterior setae, one long claw-like stiff seta reaching about to the end of the third segment, and another medium-sized seta extending to midpoint of second segment. Rome and Wouters organs not seen. Second to fifth segments without setae. Penultimate segment with three equally long distal setae. Terminal segment with two equally long setae and one slightly short aesthetasc ya. All setae of A1 smooth. Length ratio of seven segments measured on centerline: $1.00: 1.20: 0.50: 0.33: 0.33: 0.33: 0.25$.

A2 (Fig. 4B): four-segmented. First segment (protopodite) with a long claw-like postero-distal seta. Exopod absent on the second segment. Aesthetasc $Y$ three segmented, very long and whip-like. Antero-distal setae is long and about the size of the GM claw. Setae t1-4 absent. Natatory (swimming) setae and aesthetascs y1-3 not seen (cf. female). z1 and z3 setae short and about the size of terminal segment, z2 seta is claw-like and about the same size as the G2 claw. G1 claw absent, G3 seta-like about one half of the GM claw. Gm claw less than half the length of G3. Claws and setae almost smooth.

Md (Fig. 4C): Md-coxa small compared to the palp, with six to seven smooth teeth and a small seta about one half the length of the longest tooth. Dorsal seta is almost the same size as the teeth. Md-palp four-segmented. First segment with two almost equally long smooth setae (S1, S2) posteriorly, and one shorter alpha ( $\alpha$ ) seta about one third the length of the S2-seta. Vibratory plate not seen. Second segment with four (3+1) sub-equally long claw-like setae. Beta seta absent. Third segment with one well-developed claw-like slightly plumose seta posteriorly and one small seta. Gamma seta absent. Terminal segment wide, with three claws, the middle one fused with the terminal segment. The middle and posterior claws plumose, anterior claw smooth and longer than the former two claws. No setae seen on anterior edge of the segments. Length ratios of four segments measured along centerline: $1.10: 1.00: 1.00: 0.50$.

Mxl (Fig. 4D): with three endites and a palp. Vibratory plate with seven to eight long plumose setae. Base of the first endite bearing one long seta slightly plumose about the length of the palp. First and second endites bearing four 


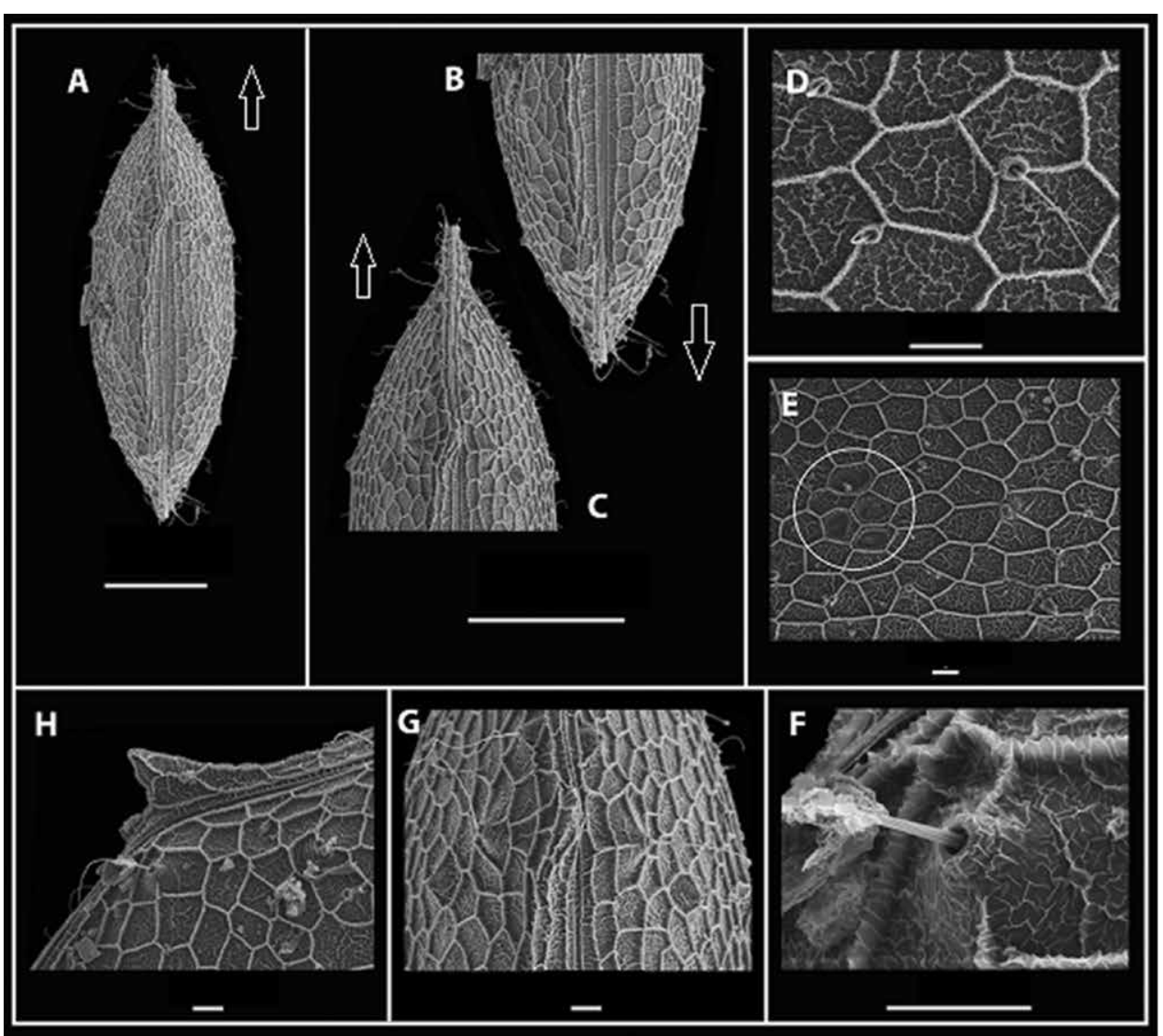

Figure 3. Cabralcandona mixoni gen. et sp. nov. female (A-C, H-G), male (D-F). A) Dorsal view of carapace; B) Dorsal view of posterior horn C) Dorsal view of anterior horn ; D) Close view of hexagonal ornamentations; E) Muscle scars; F) Close view of pore opening with sensory seta (note wrinkled cells on surface); G) Close dorsal view of anterior horn; $\mathrm{H}$ ) Lateral view of posterior horn. Scale: $10 \mu \mathrm{m}$ for D-E. Arrows point anteriorly. and six short apical setae, respectively. Third endite with one smooth bristle-like seta about one half the length of the longest seta, and two long and one short slightly plumose setae. MxI palp with elongated penultimate segment and two smooth setae, terminal segment about one quarter length of first segment, quadrate, and with three setae about the same length of two segments. Rake-like organ (Fig. 4E): comblike with small teeth. Hypostome (Fig. 4F) simple rounded.

T1 (Fig. 4G-H): with well-developed and slightly asymmetric prehensile palps. Palps not divided, distal end hook-shaped. End of apical margin of the palps with three spine-like structures and one smooth seta above these spines. Left palp slightly longer and thinner than right palp. Vibratory plate not visible. a seta absent. Setae $b, c$, and $d$ smooth and almost equally long. Masticatory process with 5 medium-sized apical setae.

T2 (Fig. 5B): five segmented with a long (d1) slightly serrated basal seta on the first segment, about the same size as the second segment. Setae dp and d2 absent. $e, f$, and $g$ setae $(e>f>g)$ present on second, third and penultimate segments, respectively. Terminal segment with one well-developed long and smooth claw (h2), reaching about half the length of the second segment. Setae h1 and h3 not seen.

T3 (Fig. 5A) four-segmented. First segment with a medium sized smooth d1 seta. d2 and dp setae absent; $e$, $f$, and $g$ setae absent. Terminal segment quadrate to trapezoidal, with three smooth claw-like setae (length: h3 = h1 $>$ h2). Setae h1 and h3 long about the length of last two segments. Hemipenis (Fig. 5C) with a rounded lobe $h$. Lobe $b$ subtriangular. Lobe a with a pointing end dorsally. M process not visible. UR flagellum like with elongated ramus. Anterior and posterior setae absent. UR attachment simple. Zenker's organ (Fig. 5D) with seven (5+2) whorls of spines, ending with a wide sperm canal.

Female: $\mathrm{L}=0.37-0.44 \mathrm{~mm}$ (average $0.41 \mathrm{~mm})(\mathrm{n}=2), \mathrm{H}=0.23-0.24 \mathrm{~mm}$ (average $0.23 \mathrm{~mm})(\mathrm{n}=2), \mathrm{W}=$ 0.14-0.14 $\mathrm{mm}$ (average $0.14 \mathrm{~mm})(\mathrm{n}=2$ ). Carapace similar to that of male in shape (Figs. 2D, 3A-C, G-H), except for slight differences in size. All G-claws on A2 smooth (Fig. 5E). A short subapical seta present on the anterior end of the penultimate segment. Aesthetascs y1 and y2 absent, aesthetasc y3 small and about the size of terminal segment. Lengths: G3 > G1 > GM > G2 > Gm. G2 claw about half length of G1 and G3 claws. Gm seta-like and about 4x the length of the terminal segment. Genital field small without appendages (Fig. 5G). All other soft parts are similar to those of the male. T1 normally developed with three subequally long h1, h2, and h3 setae on distal end of endopod (Fig. 5F). Masticatory process with 5 plumose and 1 smooth setae. One medium-sized smooth "d" seta present.

\section{Sympatric Ostracods}

In addition to Cabralcandona mixoni sp. n. et gen. n., five other hypogean ostracod species (Ufocandona hannaleeae, Rugosuscandona scharfi, Lacrimacandona wisei, Cypria lacrima, Namiotkocypria haysensis, (Külköylüoğlu et al., 2017a-d, Külköylüoğlu 2018) have also been documented at the San Marcos Artesian Well.

\section{Phylogeny}

Cluster analysis produced a majority consensus tree with 117 steps $(\mathrm{Ci}=27, \mathrm{Ri}=72)$ for the 49 genera, using the 36 morphological characters in more than 100 equally parsimonious trees (Fig. 6). Cabralcandona gen. n. is clearly 


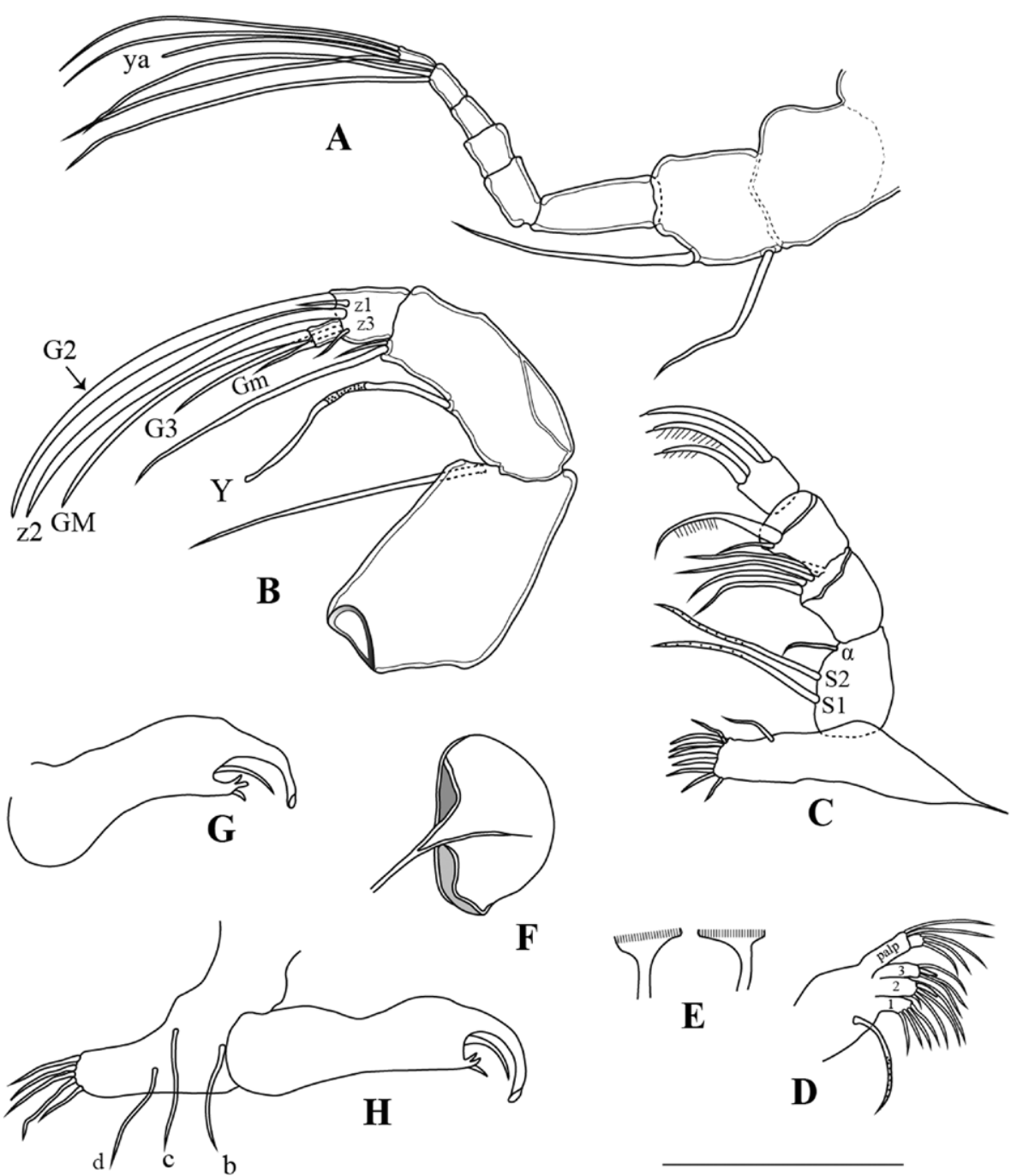

Figure 4. Cabralcandona mixoni gen. et sp. nov. Male: A) Antennule (A1); B) Antenna (A2); C) Mandible (Md); D) Maxillule (Mx1); E) Rake-like organ; F) Hypostome; G) Right clasping organ; H) Left clasping organ. Scale: $50 \mu \mathrm{m}$ for A-C, E; $40 \mu \mathrm{m}$ for D; $60 \mu \mathrm{m}$ for F; $25 \mu \mathrm{m}$ for $\mathrm{G}-\mathrm{H}$.

brasilopsis in Higuti and Martens (2012) and Abcandonopsis in Karanovic (2004).

Several characteristics distinguish Cabralcandona from other genera, notably the two horn-like structures positioned dorsally on the LV, on nearly opposite ends of the hinge. Bicornucandona bears two horns on the LV but they are located in about the center of dorsal margin. We consider these structures diagnostic for the new genus, since they are also present in juveniles. Three of the genera placed closely to each other in the new tribe (Cabralcandona gen. n., Rugosuscandona and Ufocandona) seem to exhibit more similarities with one another than with other genera. For example, all three bear hexagonal and/or pentagonal cell-type ornamentations on the carapace surface although these structures are scarce and mostly restricted to marginal zones in Ufocandona.

Külköylüoğlu et al. (2017 a-c) stressed the importance of carapace ornamentation for species identification and as indication of microhabitat characteristics. The authors point out that carapace ornamentation may be more prominent in fossil (i.e., Paleogene-Neogene) forms (Krstić, 1972; Krstić and Guan, 2000) relative to recent forms. The ornamentations unique to Cabralcandonini may imply that the tribe shares a close relationship to ancestral forms. However, without fossil representatives of the Cabralcandonini genera, this hypothesis remains unsupported. Below, we discuss some body parts, and compare each with other taxonomic groups.

Several body parts are informative about the relationship between Cabralcandonini and other taxonomic groups:

1. Muscle scars: The subfamily Candoninae and tribe Candonopsini are characterized by six (one elongated +3 anterior +2 posterior) central muscle scars (Karanovic, 2004), previously characteristic for the Candonidae family (Meisch, 2000). In Cabralcandonini, there are only five internal scars, one of which is faint or invisible in external view. Muscle scars are invisible (or not very obvious) in external view in three genera (Ufocandona, 
Rugosuscandona, Lacrimacandona) although they can be seen more clearly in Cabralcandona mixoni sp. n. et gen. n., and others (Schornikovdona, Comalcandona, Bicornucandona).

2. A1: The numbers of segments and chaetotaxy of $A 1$ differ among genera (Karanovic, 2005a, b, c). Five genera (Ufocandona, Lacrimacandona, Comalcandona, Bicornucandona, Cabralcandona gen. n.) possess about seven segments while Schornikovdona bears five segments in A1. However, Pioneercandonopsis, and both Rugosuscandona and Caribecandona possess four and six $A 1$ segments, respectively. As suggested previously (Karanovic and Marmonier (2003), Higuti and Martens (2014), Smith and Kamiya (2015), and Külköylüoğlu et al. (2017a-c, e)), a reduction in the numbers of segments of any organ or appendage (i.e., A1) likely represents a derived character state, possibly arising via paedomorphosis (Danielopol, 1978, 1980).

3. A2: Both females and males of the new genus have four segments in A2 without an exopodial plate. Although four or five A2 segments are found in different candonid genera (Karanovic, 2001, 2003a,b, 2012), absence of the exopod (or exopodial plate) is only known from Rugosus-

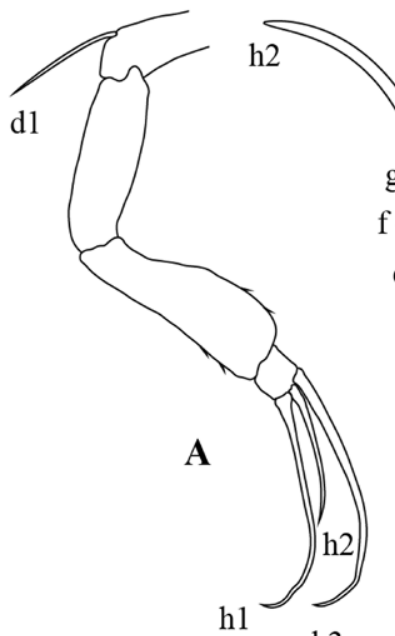

$\mathrm{h} 3$
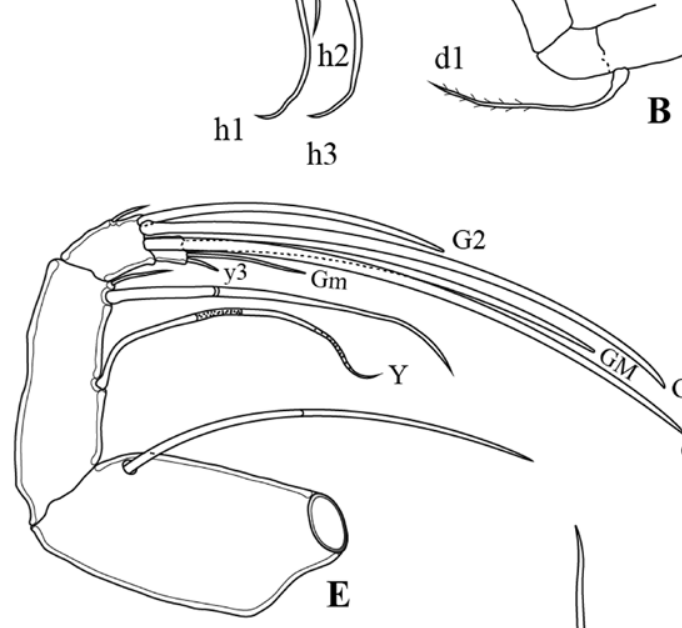

B
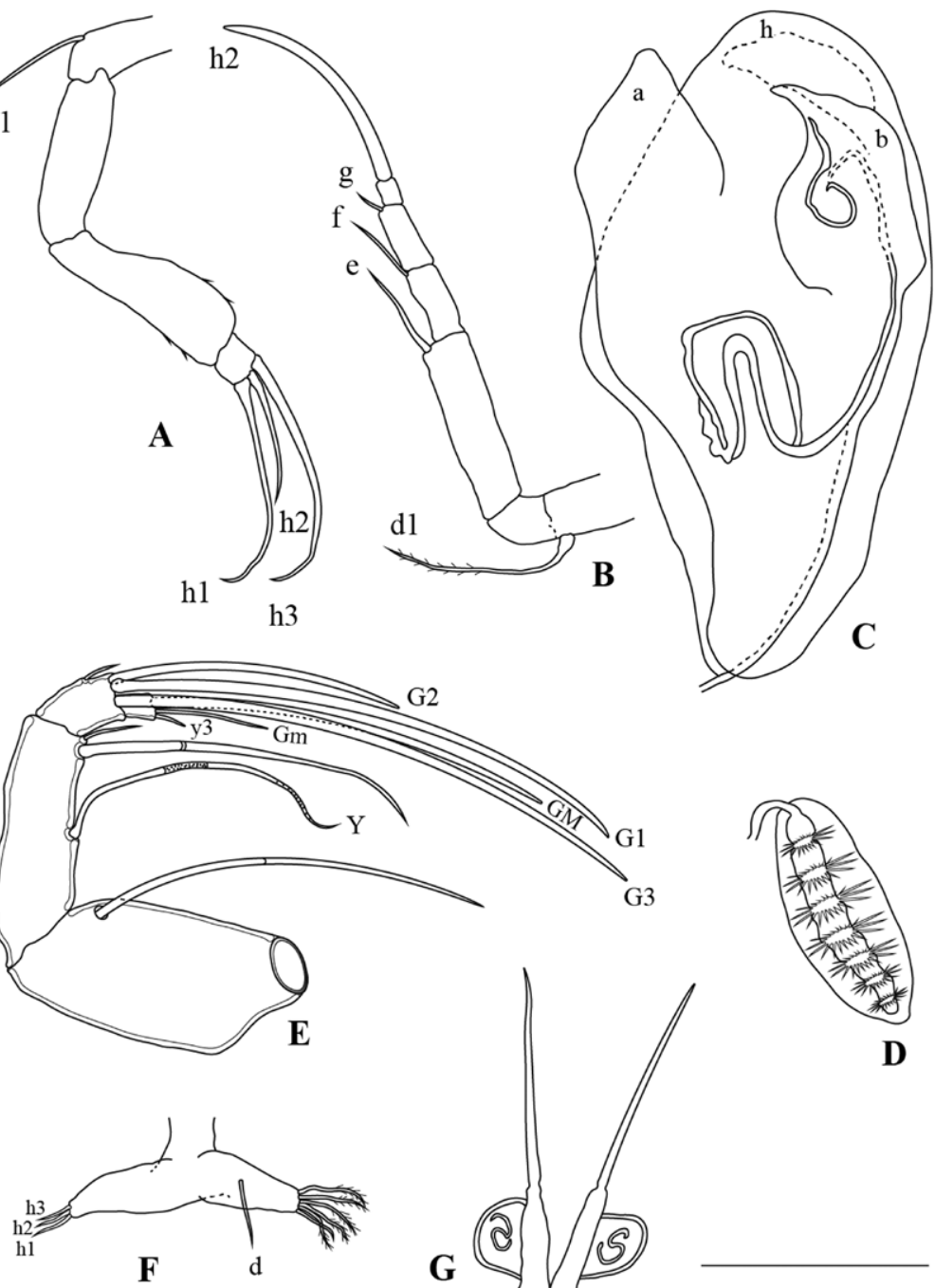

G
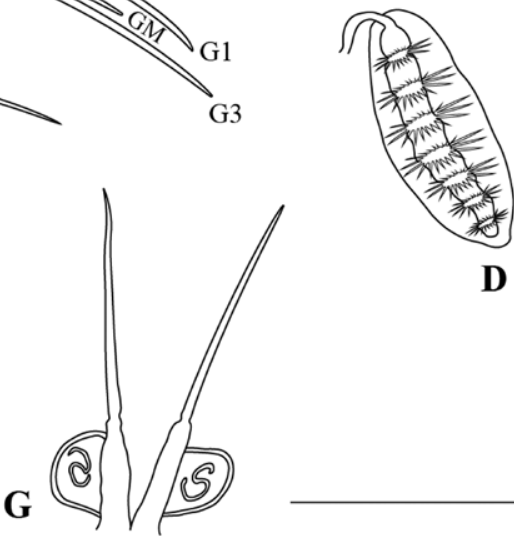

Figure 5. Cabralcandona mixoni gen. et sp. nov. A) T3; B) T2; C) Hemipenis; D) Zenker's organ; E) Female Antenna (A2); F) T1; G) Uropod of female with genital organ. Scale: $50 \mu \mathrm{m}$ for A-C, E; $60 \mu \mathrm{m}$ for D; $55 \mu \mathrm{m}$ for F-G. candona and Ufocandona (but see exception in the males of Ufocandona) (Külköylüoğlu et al., 2017a,b). There are no sensory bristles on the A2 of males of the new genus, which is similar to five other genera (Rugosuscandona, Ufocandona, Comalcandona, Cubacandona and Marococandona). The new genus exhibits a sexually dimorphic character in the length of G-claws (G1-G3, GM, Gm), similar to those seen in several other genera in the tribe Candonopsini (Karanovic, 2006; Külköylüoğlu et al., 2017c). For example, G1-G3 claws on A2 are unequally long in three genera (Lacrimacandona, Pioneercandonopsis and Meridiescandona), but several North American species (e.g., Candona peircei Turner, 1895; C. sigmoides Sharpe, 1897; C. suburbana Hoff, 1942; C. acuta Hoff, 1942; C. crogmaniana Turner, 1894; C. inopinata Furtos, 1933; C. intermedia Furtos, 1933; Eucandona rectangulata (Alm, 1914); Typhlocypris elliptica (Furtos, 1933)) bear subequally sized claws (Karanovic, 2006; Külköylüoğlu et al., 2017a-d).

4. Md-palp: This is also one of the important diagnostic characteristic that separates the new tribe Cabralcandonini from other tribes of the subfamily (Table 1). While setae in bunch on the Md palp have no setules in the new tribe, these setae bear setules in other tribes. Besides, there are important differences in the numbers and shape of setal structures of the palp between Cabralcandona gen. $n$. and other members of the subfamily. For example, only the alpha ( $\alpha$ ) seta is present (beta and gamma setae absent on the other segments) on the first segment of the palp in the new genus. While alpha seta absent in Rugosuscandona, none of these setae (alpha, beta, and gamma) are present in the genus Ufocandona. Furthermore, Cabralcandona gen. $n$. has a group of 4 claw-like setae on the second segment (diagnostic character) while some other genera have 3 (e.g., Rugosuscandona) (Külköylüoğluetal., 2017b), four(e.g., Candonopsis, Ufocandona, Comalcandona)orfive(3+2)setae(e.g., Maroco- 


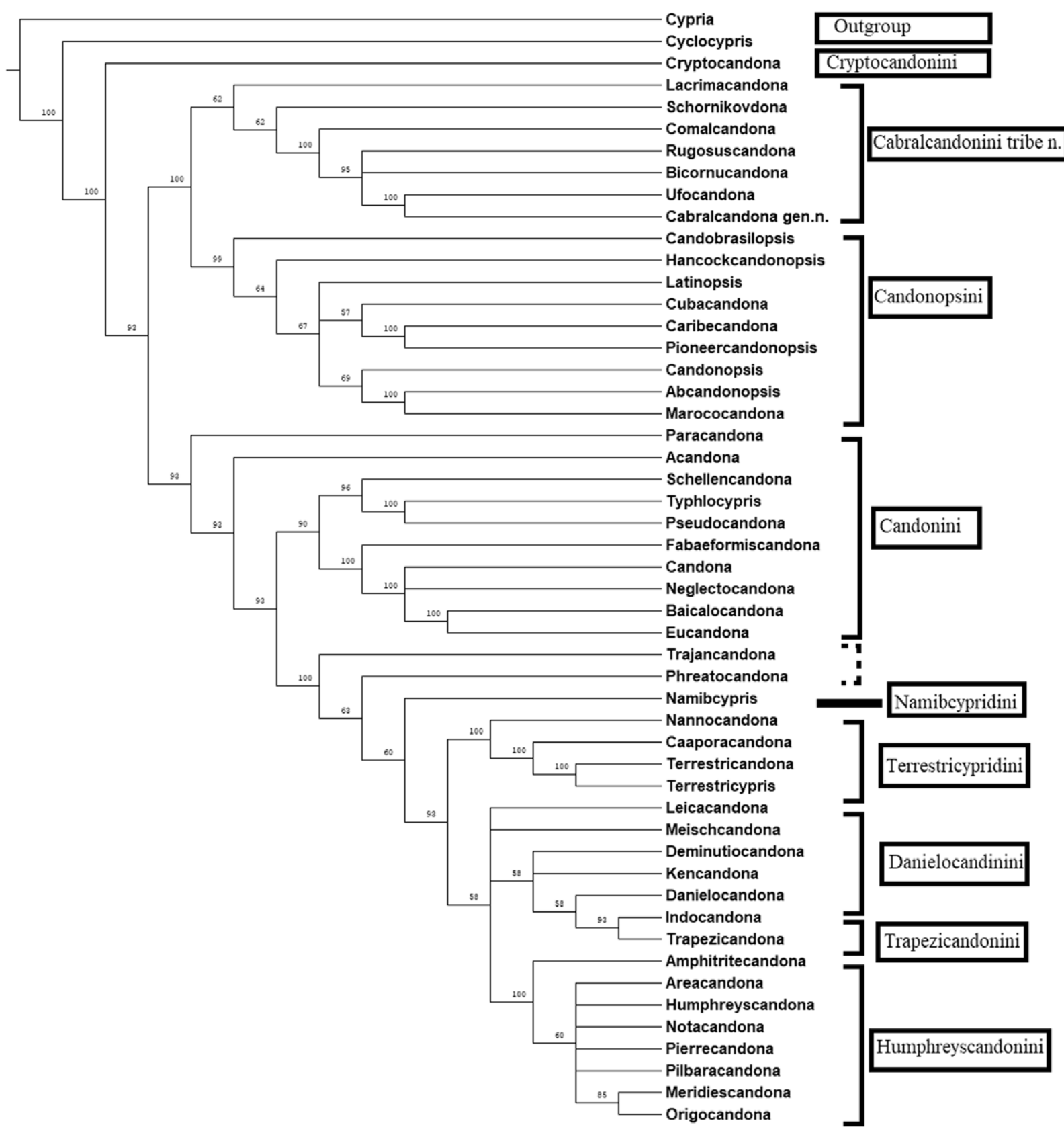

Figure 6. Clustering relationships of nine tribes of the subfamily Candoninae with Cabralcandonini tribe. n. and its new genera Cabralcandona gen. $\mathrm{n}$. candona)

( Marmonier et al., 2005). The size of the terminal s e g ment is variable a $\mathrm{m} \mathrm{o} \mathrm{n} \mathrm{g}$ genera of both tribes Cand on opsini and C a bral candonini tribe $n$. A c cord ing to the taxonom ic key of Karanovic ( 2012 ), one of the main differences between the Md-palp of Candonopsis and Latinopsis is the size of the $\mathrm{Md}$ palp. While the former has a long palp (length of terminal s e g ment more than $3 \times$ longer than width), the latter genus has a nearly square terminal segment (Karanovic and Datry, 2009). Cabralcandona gen. $\mathrm{n}$. has a relatively large terminal segment fused with the center claw. The segment is relatively large with an almost square shape. Such differences are common not only in the new tribe but also among other tribes within Candonidae (e.g., see Broodbakker, 1983; Karanovic, 2001, 2008, 2012; Karanovic and Datry, 2009; Higuti and Martens, 2012, 2014; Külköylüoğlu et al., 2017a-d).

5. Mxl: Cabralcandona gen. $\mathrm{n}$. is the only genus within the tribe that bears a short and smooth seta on the third endite of Mxl. The number of setae on the palp varies from 5 to 10 among the genera of the tribe Candonopsini but in Cabralcandona gen. $n$., there are two and three smooth setae on the penultimate and terminal segments of the palp, respectively. Ufocandona is the only genus with 5 setae, whereas the other genera have 8,9 , or 10 setae and claws (e.g., Candonopsis linnaei Karanovic, 2008). Herein, we only consider the differences in the number of setae. However, there are additional differences in the type of seta (e.g., plumose, setose or smooth: Smith and Kamiya, 2015; Karanovic, 2011; Külköylüoğlu and Gibson, 2018). 
6. T1: Cabralcandona gen. $n$. has nearly symmetrical male prehensile palps, like three other genera of the subfamily Candoninae (cf. Latinopsis, Pioneercandona, Rugosuscandona). The absence of a vibratory plate in T1 in Cabralcandona gen. $\mathrm{n}$. is also unusual, first reported for Rugosuscandona, and not common in members of the tribe Candonopsini. Additionally, Rugosuscandona and Cabralcandona gen. $\mathrm{n}$. are the only genera in the new tribe that do not have a seta. This warrants further investigation since description of this seta along with others ( $b, c, d$ setae) can be difficult due to their small size.

7. T2-T3: The numbers of setae (e, $f, g$ and basal (d1) setae) on T2 in the new genus is similar to related genera (but compare the type and size of setae in Külköylüoğlu et al., 2017a-d; Külköylüoğlu and Gibson, 2018) except for Cubacandona, Candonopsis and Lacrimacandona. In contrast, T3 of Cabralcandona gen. n. has only one basal (d1) seta and no $e, f, g$ setae, similar to Rugosuscandona. Considering that all other genera of the new tribe bear at least two basal and one of the three other setae, the reduced setation on thoracic legs may be an additional adaptation to underground environments.

8. UR: Cabralcandona gen. $\mathrm{n}$. has a flagellum type UR (diagnostic character of the genus) that is very similar to members of the subfamily Cypridopsinae. This character is also present in Ufocandona and Rugosuscandona. Two claws and two setae on UR is a common character state in cypridoid ostracods (Meisch, 2000) although the appendage is variable among members of Candoninae. Caribecandona (Broodbakker, 1983), Indocandona (Gupta, 1984), Candonopsis (e.g., see Candonopsis (Abcandonopsis) aula) (Karanovic, 2004), and Bicornucandona (Külköylüoğlu et al., 2011) have a single claw on the UR while Lacrimacandona has two small claws. A flagellum (or whip-like) type UR is very rare among the species of Candoninae (but see e.g., Danielocandona lieshoutae (Broodbakker, 1983)). Once again, the new genus exhibits a reduction in soft body parts. Indeed, McKenzie (1982) and Higuti and Martens (2012) pointed out that such reduction in size and chaetotaxy in the uropodal ramus of cypridoid species has occurred many times in different lineages, as an example of parallel evolution (homeomorphy) in non-marine ostracods. Knowledge about increased appendage length or reduction may provide additional understanding about habitat type. For example, in amphipods and isopods, increased setation and increased appendage length is often associated with open water type subterranean habitats (i.e. phreatic zones, vadose zones) while reduced setation and reduced appendage length is often associated with closed water type habitats (i.e. hyporheic zones) (Marmonier et al., 2005; Culver and Pipan, 2009).

9. Zenker's Organ: The new genus has $5+2$ whorls of spines on the Zenker's organ. A similar pattern can be found in the members of the tribe Candonopsini (see discussion in Külköylüoğlu et al., 2017b, c).

10. Hemipenis: Cabralcandona gen. $\mathrm{n}$. has a relatively small hemipenis (and Zenker's Organ) compared to other genera (e.g., cf. Lacrimacandona, Rugosuscandona). We were not able to observe an M-process in the hemipenis, but other parts (lobes) are unique to the genus. For example, lobe a with a sharp pointing end is clearly visible.

Cabralcandona gen. $\mathrm{n}$. and two other congenera (Rugosuscandona and Ufocandona) are closely separated from others and clustered in the new tribe (Fig. 6). Although these three genera show clear morphological differences at the genetic level, they also share the following characters (Table 1) in common: 1) carapace ornamented with hexagonal or pentagonal cells, 2) numbers of segments in A2, 3) absence of t seta on A2, 4) absence of gamma seta on Md, 5) absence of seta a on T1, 6) presence of basal seta on T2 and T3, 7) absence of seta e on T3, 8) two long and one short setae on T3, 9) presence of rod-like (flagellum) claw on UR, 10) square or medial lobe in hemipenis. The tribe Candonopsini (Candoninae, Candonidae) previously included 13 subgenera (Abcandonopsis, Candobrasilopsis, Candonopsis, Caribecandona, Comalcandona, Cubacandona, Hancockcandonopsis, Lacrimacandona, Latinopsis, Marococandona, Pioneercandonopsis, Rugosuscandona, Ufocandona) but four genera (Comalcandona, Lacrimacandona, Rugosuscandona, Ufocandona) are now transferred to the new tribe Cabralcandonini tribe $\mathrm{n}$.

Relationships among genera depicted in Figure 6 differ from the consensus tree of Karanovic (2007), because of potential factors including 1) the use of additional characters (e.g., absence of exopod in A2, flagellum-like UR), and 2) the number of genera included (49 versus 39 (sub)genera). Presence of polytomies among some genera also suggests that the number of characters may not be enough to discriminate clustering groups. Based on the cluster tree (Fig. 6), four other genera (Bicornucandona, Comalcandona, Lacrimacandona, Schornikovdona) can be tentatively placed with three closely related genera (Cabralcandona gen. n., Rugosuscandona, Ufocandona) of the new tribe. Considering that all these seven genera are found from the same geographic location and similar habitats (artesian well and/ or spring waters), placement of these genera into the new tribe may be supported by the cluster tree. However, this placement does not correspond to the most current taxonomic keys (e.g., see Karanovic, 2007, 2012, 2018), in which some of these genera have already been described in other tribes. For example, presence or absence of posterior seta on the uropod is one of the main taxonomic character states separating the two close tribes Candonini (seta present) and Candonopsini (seta absent) (Karanovic, 2012). Following the key, for example, two genera (Bicornucandona and 
Schornikovdona) belong to the tribe Candonini while two others (Comalcandona, Lacrimacandona) are placed in the tribe Candonopsini. Similarly, Trajancandona and Phreatocandona are supposed to be found in the tribe Candonini but the tree (Fig. 6) apparently separates these two from others. Although Karanovic (2007) reached a similar result, she included these two genera into the tribe Candonini following the taxonomic key. Relatively high $\mathrm{Ci}$ and $\mathrm{Ri}$ values suggest considerable uncertainty in the placement of genera within tribes because of a high degree of homoplasy. Karanovic $(2007,2018)$ emphasized that the phylogeny and evolution of Candonopsini needs to be investigated with molecular data (also see Hiruta et al., 2016). Although we agree that molecular data is valuable for phylogenetic analysis, obtaining adequate sample size across all or most taxa can present a challenge for construction of comprehensive molecular-based phylogenies.

\section{Adaptations and Ecology}

According to Marmonier et al. (2005, and references therein), and Külköylüoğlu et al. (2017b,c), hypogean (groundwater) ostracods may exhibit at least seven different morphological and reproductive specializations to groundwater conditions: 1) smaller body size, 2) anopthalmy or reduction in eye pigmentation, 3) reduction or loss of appendage length and setation, 4) changes in carapace shape, 5) elongation in appendages (e.g. legs and/or claws) or sensory setae (e.g., $Y$ aesthetasc), 6) reduction of some extremities in males, 8) increase in egg size. Almost all genera in Cabralcandonini tribe $\mathrm{n}$. exhibit these adaptations, although we currently do not have information on reproductive characteristics, including clutch and egg size. Overall, these adaptations clearly suggest that members of Cabralcandona gen. n. are restricted to hypogean habitats. Additionally, we can make some hypotheses about microhabitats in which these species may occur. For example, Ufocandona hannaleeae possesses asymmetric valves (oval LV and more subrectangular RV) while Rugosuscandona wisei and Cabralcandona mixoni sp. $\mathrm{n}$. are rectangular and subrectangular in shape, respectively. According to Pipík and Bodergat $(2005,2007)$, some Candonine species with triangular and rectangular carapaces and a pointed posteroventral margin inhabit relatively stable habitats with minimal environmental fluctuations and species with a subcircular outline (e.g., Cypria) inhabit unstable environments.

\section{Conclusions}

Based on the characteristics discussed above, we propose Cabralcandonini tribe $\mathrm{n}$. as a new tribe of the subfamily Candoninae. Hence, there are now nine tribes (Candonini Kaufmann, 1900; Candonopsini Karanovic, 2004; Cryptocandonini Karanovic, 2007; Danielocandonini Karanovic, 2007; Humphreyscandonini Karanovic, 2005, Namibcypridini Martens, 1992; Terrestricypridini Pinto et al., 2005; Trapezicandonini Karanovic, 2007, Cabralcandonini tribe $\mathrm{n}$. Külköylüoğlu et al., in here) in the subfamily. However, ongoing studies strongly suggest that ostracod species diversity in at least some underground waters is unique and higher than currently acknowledged.

\section{Key to the Tribes of Subfamily Candoninae: (Modified from Karanovic 2012).}

1. Setae in bunch on Md palp without row of setules............................Cabralcandonini tribe $\mathrm{n}$.

- Setae in bunch on Md palp with row of setules........................................................... 2

2. Terminal segment of T3 with one long claw............................Terrestricypridini

- Terminal segment of T3 without long claw............................................

3. Terminal segment of T3 with two long and one short setae ............................

- Terminal segment of T3 with two short and one long setae...........................6

4. T3 without basal seta.................................................mibcypridini

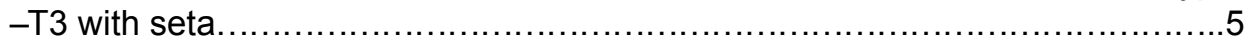

5. Posterior seta on the UR present......................................... Candonini

- Posterior seta on the UR absent.................................... Candonopsini

6. Chitinized projection on the inner lobe of hemipenis present............Humphreyscandonini

- Chitinized projection on the inner lobe of hemipenis absent.............................

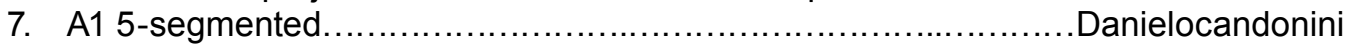

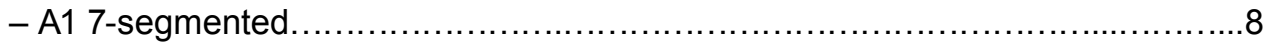

8. Basal seta on T2 present, outer lobe on hemipenis robust...................Cryptocandonini

- Basal seta on T2 absent, outer lobe on the hemipenis thin.................Trapezicandonini

\section{Acknowledgements}

We thank Kristen Porter-Utley (Bartlett College of Science and Mathematics, Bridgewater State University) and Serdar Dinç (Bolu Abant İzet Baysal University) for their help obtaining information about the WinClada program. Weston Nowlin, Zachary Schwartz, Jonny Scalise, and Aaron P. Swink are acknowledged for providing facilities and assisting with sorting raw samples and counting ostracods at the Freeman Aquatic Center, Texas State University. Cem Berk (The Scientific and Technological Research Council of Turkey - Marmara Research Center, Kocaeli, Turkey) and Dr. Michael K. Opoku (Research Service Center, Texas State University, Texas, U.S.A.) are thanked for their help 
on SEM photography. We also thank the Department of Biology (Texas State University) and the Fulbright Research Scholarship program for their support.

\section{References}

Benson, R.H., 1990, Ostracoda and the discovery of global Cainozoic palaeoceanographical events, in Whatley, R., and Maybury, C., eds., Ostracoda and Global Events: Chapman and Hall, Cambridge, p. 41-59.

Bromley, H.J., and Por, F.D., 1975, The metazoan fauna of a sewage-carrying wadi, Nahal Soreq (Judean Hills, Israel): Freshwater Biology, v. 5, p. 121-133. https://doi.org/10.1111/j.1365-2427.1975.tb00126.x.

Broodbakker, N.W., 1983, The subfamily Candoninae (Crustacea, Ostracoda) in the West Indies: Bijdragen tot de Dierkunde, v. 53, p. $287-326$.

Broodbakker, N.W., and Danielopol, D.L., 1982, The chaetotaxy of Cypridacea (Crustacea, Ostracoda) limbs: proposals for a descriptive model: Bijdragen tot de Dierkunde, v. 52, p. 103-120.

Carpenter, L.G., 1891, The artesian wells of Colorado and their relation to irrigation, in The State Agricultural College, The Agricultural Experiment Station, Bulletin No.16: Fort Collins, Colorado, p. 1-28.

Chaplin, J.A., and Ayre, D.J., 1997, Genetic evidence of widespread dispersal in a parthenogenetic freshwater ostracod: Heredity, v. 78, p. 57-67. https://doi.org/10.1038/hdy.1997.7.

Chippindale, P.T., 2000, Species boundaries and species diversity in the Central Texas Hemidactyliine Plethodontid salamanders, genus Eurycea, in Bruce, R.C., Jaeger, R.G., and Houck, L.D., eds., The Biology of Plethodontid Salamanders: Boston, Springer, 149-165. https://doi. org/10.1007/978-1-4615-4255-1_6.

Chivas, A.R., De Deckker, P., and Shelley, J.M.G., 1986, Magnesium and strontium in non-marine ostracod shells as indicators of palaeosalinity and palaeotemperature: Hydrobiologia, v. 143, p. 135-142. https://doi.org/10.1007/BF00026656.

Cohen, A.S., and Johnston, M.R., 1987, Speciation in brooding and poorly dispersing lacustrine organisms: Palaios, v. 5, p. 426-435. https://doi. org/10.2307/3514614.

Culver, D.C., and Pipan. T., 2009, Biology of caves and other subterranean habitats: Oxford, Oxford University Press, 272 p.

Culver, D.C., and Sket, B., 2000, Hotspots of subterranean biodiversity in caves and wells: Journal of Cave and Karst Studies, v. 62, p. $11-17$.

Danielopol, D.L., 1978, Über Herkunft und Morphologie der Süsswasser-hypogäischen Candoninae (Crustacea, Ostracoda): Sitzungsberichte Österreichische Akademie der Wissenschaften Mathematisch-Naturwissenschaftliche, KI. (I) 187, p. 1-162.

Danielopol, D.L., 1980, An essay to assess the age of the freshwater interstitial ostracods of Europe: Bijdragen tot de Dierkunde, v. 50, p. 243-291.

Danielopol, D.L., Baltanás, A., Morocutti, U., and Österreicher, F., 2011, On the need to renew the taxonomic system of the Candoninae (Non-Marine Ostracoda, Crustacea). Reflexions from an analysis of data using the Yule Process: Geo-Eco-Marina 17: $195-210$.

De Deckker, P., 1981, Taxonomy and ecological notes of some ostracods from Australian inland waters: Transactions of the Royal Society of South Australia, v. 105, p. 91-138.

Díaz, A.R., and Lopretto, E.C., 2017, Postembryonic development of nonmarine ostracod Chlamydotheca arcuata (Sars, 1901) (Crustacea: Ostracoda), reared in the laboratory: Turkish Journal of Zoology, v. 41, p. 209-226. https://doi.org/10.3906/zoo-1512-13.

Garza, S.J., Wilson, K.R., and Bowser, G., 2015, Removal of artesian wells in Great Sand Dunes National Park and its aftermath on small mammals, plant cover, and area disturbance by ungulates: Park Science, v. 32, p. 57-64.

Higuti, J., and Martens, K., 2012, Description of a new genus and species of Candonopsini (Crustacea, Ostracoda, Candoninae) from the alluvial valley of the Upper Paraná River (Brazil, South America): European Journal of Taxonomy, v. 33 p. 1-31. https://doi.org/10.5852/ejt.2012.33.

Higuti, J., and Martens, K., 2014, Five new species of Candoninae (Crustacea, Ostracoda) from the alluvial valley of the Upper Paraná River (Brazil, South America): European Journal of Taxonomy, v. 106, p. 1-36. https://doi.org/10.5852/ejt.2014.106.

Hiruta, S.F., Kobayashi, N., Katoh, T., and Kajihara, H., 2016, Molecular phylogeny of cypridoid freshwater Ostracods (Crustacea: Ostracoda), inferred from 18S and 28S rDNA sequences: Zoological Science, v. 33, p. 179-185. https://doi.org/10.2108/zs150103.

Hoff, C.C., 1942, The Ostracods of Illinois: Illinois Biological Monographs, v. 19, p. 1-196.

Holsinger, J.R., and Longley, G., 1980, The subterranean amphipod crustacean fauna of an artesian well in Texas: Smithsonian Contributions to Zoology, v. 308, p. 1-62. https://doi.org/10.5479/si.00810282.308.

Hutchins, B.T., 2018, The conservation status of Texas groundwater invertebrates: Biodiversity and Conservation, v. 27, p. 475-501. https://doi. org/10.1007/s10531-017-1447-0.

Hutchins, B.T., Engel, A.S., Nowlin, W.H., and Schwartz, B.F., 2016, Chemolithoautotrophy supports macroinvertebrate food webs and affects diversity and stability in groundwater communities: Ecology, v. 97, p. 1530-1542. https://doi.org/10.1890/15-1129.1.

Hutchins, B.T., Schwartz, B.F., and Nowlin, W.H., 2014, Morphological and trophic specialization in a subterranean amphipod assemblage: Freshwater Biology, v. 59, p. 2447-2461. https://doi.org/10.1111/fwb.12440.

Karanovic, I., 2001, Meischcandona gen. nov. from Africa, with a key to the genera of the subfamily Candoninae (Crustacea, Ostracoda): Bulletin de l'Institut Royal des Sciences Naturelles de Belgique Biologie, v. 71, p. 93-99.

Karanovic, I., 2003a, Towards a revision of Candoninae (Crustacea: Ostracoda): description of two new genera from Australian groundwaters: Species Diversity, v. 8, p. 353-383. https://doi.org/10.12782/specdiv.8.353.

Karanovic, I., 2003b, A new genus of Candoninae (Crustacea, Ostracoda, Candonidae) from the subterranean waters of southwestern Western Australia: Records of the Western Australian Museum, v. 21, p. 315-332. https://doi.org/10.18195/issn.0312-3162.21(4).2003.315-332.

Karanovic, I., 2004, Towards a revision of Candoninae (Crustacea, Ostracoda): on the genus Candonopsis Vávra, with descriptions of new taxa: Subterranean Biology, v. 2, p. 91-108.

Karanovic, I., 2005a, Towards a revision of Candoninae (Crustacea: Ostracoda): Australian representatives of the subfamily, with descriptions of three new genera and seven new species: New Zealand Journal of Marine and Freshwater Research, v. 39, p. 29-75. https://doi.org/10.1080/ 00288330.2005 .9517292$.

Karanovic, I., 2005b, Comparative morphology of the Candoninae antennula, with remarks on the ancestral state in ostracods (Crustacea, Ostracoda) and proposed new terminology: Spixiana, v. 28, p. 141-160.

Karanovic, I., 2005c, A new Candoninae genus (Crustacea: Ostracoda) from subterranean waters of Queensland, with a cladistic analysis of the tribe Candonopsini: Memoires of the Queensland Museum, v. 50, p. 303-319.

Karanovic, I., 2006, Recent Candoninae (Crustacea, Ostracoda, Candonidae) of North America: Records of the Western Australian Museum, v. 71, p. 1-75. https://doi.org/10.18195/issn.0313-122x.71.2006.001-075. 
Karanovic, I., 2007, Candoninae ostracodes from the Pilbara region in Western Australia: Crustaceana Monographs (Brill, Leiden), v. 7, p. 1-432. https://doi.org/10.1163/ej.9789004156937.i-434.

Karanovic, I., 2008, A new species of the genus Candonopsis (Crustacea, Ostracoda) from Western Australia: Records of the Western Australian Museum, v. 24, p. 411-419. https://doi.org/10.18195/issn.0312-3162.24(4).2008.411-419.

Karanovic, I., 2011, On the recent Cyclocypridinae (Podocopida, Candonidae) with description of two new genera and one new species: Zootaxa 2820: 1-61. https://doi.org/10.11646/zootaxa.2820.1.1.

Karanovic, I., 2012, Recent freshwater Ostracods of the world: Crustacea, Ostracoda, Podocopida: Heidelberg, Springer Publishing, 608 p. https://doi.org/10.1007/978-3-642-21810-1

Karanovic, I., 2013, Earicandona, new genus and the first record of Typhlocypris pratensis (Crustacea, Ostracoda) from South Korea: Journal of Species Research, v. 2, p. 145-158. https://doi.org/10.12651/JSR.2013.2.2.145

Karanovic, I., 2018, A new Candonopsini (Ostracoda) genus from subterranean waters of New South Wales (Australia): Zootaxa, v. 4379, p. 247-267. https://doi.org/10.11646/zootaxa.4379.2.6.

Karanovic, I., and Datry, T, 2009, Overview of Candoninae (Crustacea, Ostracoda) of South America and the West Indies, with the description of two new species and one new genus: Zootaxa, v. 2267, p. 1-25. https://doi.org/10.11646/zootaxa.2267.1.1.

Karanovic, I., and Marmonier, P., 2003, Three new genera and nine new species of the subfamily Candoninae (Crustacea, Ostracoda, Podocopida) from the Pilbara region (Western Australia): Beaufortia, v. 53, p. 1-51.

Kesling, R.V., and Crafts, F.C., 1962, Ontogenetic increase in Archimedean weight of the ostracod Chlamydotheca unispinosa (Baird): American Midland Naturalist, v. 68, p. 149-153. https://doi.org/10.2307/2422641.

Krstić, N., 1972, Rod Candona (Ostracoda) iz kongerijskikh slojeva juzhnog dela Panonskog basena (Genus Candona (Ostracoda) from Congeria beds of Southern Pannonian Basin): The Serbian Academy of Sciences and Arts, Section of Natural and Mathematical Sciences, Monographs v. 9, p. 1-145.

Krstić, N., and Guan, S., 2000, A proposal for the systematics of the subfamily Candoninae ostracodes with the description of the Macedocandona, new genus: Geologica Macedonica, v. 14, p. 25-48.

Külköylüoğlu, O., 1998, Freshwater Ostracoda (Crustacea) and their quarterly occurrence in Şamlar Lake (İstanbul, Turkey): Limnologica, v. 28, p. 229-235.

Külköylüoğlu, O., 2009, Ecological succession of freshwater Ostracoda (Crustacea) in a newly developed rheocrene spring (Bolu, Turkey): Turkish Journal of Zoology, v. 33, p. 115-123.

Külköylüoğlu, O., 2018, A new genus and species in the ostracod family Candonidae (Crustacea: Ostracoda) from Texas, USA: Journal of Natural History, v. 52, p. 1295-1310. https://doi.org/10.1080/00222933.2018.1456574.

Külköylüoğlu, O., and Gibson, R., 2018, A new Ostracoda (Crustacea) genus, Comalcandona gen. nov., from Texas, U.S.A.: Turkish Journal of Zoology, v. 42, p. 18-28. https://doi.org/10.3906/zoo-1611-52.

Külköylüoğlu, O., Gibson, R., Diaz, P.H., and Colin, J.P., 2011, Bicornucandona gen. nov., sp. nov. (Crustacea, Ostracoda) from Finegan Springs (Texas, U.S.A.): Zootaxa, v. 3059, p. 47-58. https://doi.org/10.11646/zootaxa.3059.1.3.

Külköylüoğlu, O., Yavuzatmaca, M., Akdemir, D., Schwartz, B., and Hutchins, B., 2017a, A new genus (Ufocandona n. gen.) of Ostracoda (Crustacea) from an artesian well, Texas, North America: European Journal of Taxonomy, v. 372, p. 1-18.

Külköylüoğlu, O., Akdemir, D., Yavuzatmaca, M., Schwartz, B., and Hutchins, B., 2017b, Rugosuscandona, a new genus of Candonidae (Crustacea, Ostracoda) from Texas, North America: Species Diversity, v. 22, p. 175-185.

Külköylüoğlu, O., Akdemir, D., Yavuzatmaca, M., Schwartz, B., and Hutchins, B., 2017c, Lacrimacandona n. gen. (Crustacea: Ostracoda: Candonidae) from the Edwards Aquifer, Texas (U.S.A.): Zootaxa, v. 4277, p. 261-273. https://doi.org/10.11646/zootaxa.4277.2.6.

Külköylüoğlu, O., Akdemir, D., Yavuzatmaca, M., Schwartz, B., and Hutchins, B., 2017d, Cypria lacrima sp. nov. a new Ostracoda (Candonidae, Crustacea) species from Texas, U.S.A.: Zoological Studies, v. 56, p. 15. doi:10.6620/ZS.2017.56-15.

Külköylüoğlu, O., Yavuzatmaca, M., Akdemir, D., Diaz, P.H., and Gibson, R., 2017e, On Schornikovdona gen. nov. (Ostracoda, Candonidae) from rheocrene springs in Texas (U.S.A.): Crustaceana, v. 90, p. 1443-1461. https://doi.org/10.1163/15685403-00003707.

Külköylüoğlu, O., and Vinyard, G.L., 2000, The distribution and the ecology of the freshwater Ostracoda (Crustacea) collected from springs of Nevada, Idaho, and Oregon: A preliminary study: Western North American Naturalist, v. 60, p. 291-303.

Longley, G., 1981, The Edwards Aquifer: Earth's most diverse groundwater ecosystem?: International Journal of Speleology, v. 11, p. $123-128$. https://doi.org/10.5038/1827-806X.11.1.12.

Lopez, L.C.S., Gonçalves, D.A., Mantovani, A., and Rios, R.I., 2002, Bromeliad ostracods pass through amphibian (Scinaxax perpusillus) and mammalian guts alive: Hydrobiologia, v. 485, p. 209-211. https://doi.org/10.1023/A:1021315223774.

Lopez, M.L.D., Magbanua, F.S., Mamaril, A.C., and Papa, R.D.S., 2017, Variations in microcrustacean (Crustacea: Cladocera, Copepoda) assemblages from selected groundwater-dependent ecosystems in the greater Luzon and Mindoro Island faunal regions (Philippines): insights to tropical groundwater ecology: Inland Waters, v. 7, p. 428-439. https://doi.org/10.1080/20442041.2017.1368597.

Marmonier, P., Boulal, M., and Idbennacer, B., 2005, Marococandona, a new genus of Candonidae (Crustacea, Ostracoda) from southern Morocco: morphological characteristics and ecological requirements: International Journal of Limnology, v. 41, p. 57-71. https://doi.org/10.1051/ $\operatorname{limn} / 2005006$.

Martens, K., 1987, Homology and functional morphology of the sexual dimorphism in the antenna of Sclerocypris Sars, 1924 (Crustacea, Ostracoda, Megalocypridinae): Bijdragen tot de Dierkunde, v. 57, p. 183-190.

Martens, K., and Savatenalinton, S., 2011, A subjective checklist of the Recent, free-living, non-marine Ostracoda (Crustacea): Zootaxa, v. 2855, p. 1-79. https://doi.org/10.11646/zootaxa.2855.1.1.

McKenzie, K.G., 1982, Homeomorphy: Persistant joker in the taxonomic pack, with the description of Bradleycypris gen. nov. in Bate RH, Robinson E, Sheppard LM (Eds.), Fossil and Recent Ostracods: Chichester, Ellis Horwood Ltd., p. 407-438.

Meisch, C., 2000, Freshwater Ostracoda of Western and Central Europe (Süsswasserfauna von Mitteleuropa): Heidelberg, Spektrum Akad, Verlag / Gustav Fischer, 522 p.

Mezquita, F., Tapia, G., and Roca, R.C., 1999, Ostracoda from springs on the eastern Iberian Peninsula: Ecology, biogeography and paleolimnological implications: Palaeogeography, Palaeoclimatology, Paleoecology, v. 148, p. 65-85. https://doi.org/10.1016/S0031-0182(98)00176-X.

Nixon, K.C., 2002, WinClada version 1.00.08: Ithaca, N.Y., Published by the author.

Ogden, A.E., Quick, R.A., and Rothermel, S.R., 1986, Hydrochemistry of the Comal, Hueco, and San Marcos Springs, Edwards Aquifer, Texas, in Abbott, P.L., Jr., and Woodruff, C.M., eds., The Balcones Escarpment: Geology, Hydrology, Ecology and Social Development in Central Texas: San Antonio, Tex., Geological Society of America, p. 115-131. 
Pipík, R., and Bodergat, A.M., 2005, Espèces du groupe de Candona candida, Candona neglecta et quelques Candona à l'aspect morphologique problématique (Candonidae, Ostracoda) du Bassin de Turiec (Miocène supérieur, Slovaquie): Annales de Paléontologie, v. 91, p. 279-309. https://doi.org/10.1016/j.annpal.2005.05.003.

Pipik, R., and Bodergat, A.M., 2007, Candoninae trapézoïdales (Crustacea, Ostracoda) du Bassin de Turiec (Slovaquie) du Miocène supérieur: systématique, écologie et évolution. Upper Miocene trapezoidal Candoninae (Crustacea, Ostracoda) of the Turiec Basin (Slovakia): Systematics, ecology and evolution: Geobios, v. 40, p. 645-676. https://doi.org/10.1016/j.geobios.2006.02.003.

Ponder, W.F., 2004, Endemic aquatic macroinvertebrates of artesian springs of the Great Artesian Basin - progress and future directions: Records of the South Australian Museum Monograph Series, v. 7, p. 101-110.

Schwartz, B.F., Hutchins, B.T., Schwartz, Z.G., Hess, A.J., and Bonett, R.M., 2018,

Cirolanides wassenichae sp. nov., a freshwater, subterranean Cirolanidae (Isopoda, Cymothoida) with additional records of other species from Texas, United States: Zootaxa, v. 37, p. 7-61. doi: 10.1016/j.anndiagpath.2018.08.004.

Siveter, D.J., 2008, Ostracods in the Palaeozoic?, Senckenbergiana lethaea, v. 88, p. 1-9. https://doi.org/10.1007/BF03043973.

Smith, R.J., 2011, Groundwater, spring and interstitial Ostracoda (Crustacea) from Shiga Prefecture, Japan, including descriptions of three new species and one new genus: Zootaxa, v. 3140, p. 15-37. https://doi.org/10.11646/zootaxa.3140.1.2.

Smith, R.J., and Kamiya, T., 2015, Four new species of the subfamily Candoninae (Crustacea, Ostracoda) from freshwater habitats in Japan: European Journal of Taxonomy, v. 136, p. 1-34. https://doi.org/10.5852/ejt.2015.136.

Smith, R.J., and Martens, K., 2000, The ontogeny of the cypridid ostracod Eucypris virens (Jurine, 1820) (Crustacea, Ostracoda): Hydrobiologia, v. 419, p. 31-63. https://doi.org/10.1007/978-94-017-1508-9_3.

Stejneger, L., 1896, Description of a new genus and species of blind tailed batrachian from the subterranean waters of Texas: Proceedings of the United States National Museum, v. 18, p. 619-621. https://doi.org/10.5479/si.00963801.1088.619.

Tuncer, A., and Tunoğlu, C., 2015, Early Pleistocene (Calabrian) Ostracoda assemblage and paleoenvironmental characteristics of the Fevzipaşa Formation, Western Anatolia: Micropaleontology, v. 61, p. 69-83.

Tunoğlu, C., 2002, Pontian Leptocytheridae and Cytheridae (Ostracoda) species from the eastern Black Sea Region of Turkey: Geologica Carpathica, v. 53, p. 333-346.

Ulrich, C.J. 1902, A contribution to the subterranean fauna of Texas: Transactions of the American Microscopical Society, v. 23, p. 83-102.

Williams, M., Siveter, D.J., Salas, M.J., Vannier, J., Popov, L.E., and Pour, M.G., 2008, The earliest ostracods: the geological evidence: Senckenbergiana lethaea, v. 88, p. 11. https://doi.org/10.1007/BF03043974.

Wise, C.D., 1961, Taxonomy and Ecology of freshwater ostracods of south-central Texas [Ph.D. thesis]: New Mexico, University of New Mexico. p.334. 